\title{
LABOUR CONSUMPTION OF PRODUCTION OF SELECTED FRUIT $^{1}$
}

\author{
Zbigniew Kowalczyk ${ }^{*}$, Katarzyna Grotkiewicz
}

Institute of Agricultural Engineering and Informatics, University of Agriculture in Krakow, Poland

${ }^{*}$ Corresponding author: e-mail: Zbigniew.Kowalczyk@ur.krakow.pl

\begin{tabular}{|c|c|}
\hline ARTICLE INFO & ABSTRACT \\
\hline $\begin{array}{l}\text { Article history: } \\
\text { Received: January } 2018 \\
\text { Received in the revised form: } \\
\text { April } 2018 \\
\text { Accepted: June } 2018 \\
\end{array}$ & \multirow{2}{*}{$\begin{array}{l}\text { The objective of the paper was to analyse the expenditures of labour in } \\
\text { production of three selected fruit types (apples, black currant and } \\
\text { gooseberry) including, inter alia, in relation to the surface area of } \\
\text { a plantation. The total inputs of labour were calculated with a division } \\
\text { into manual and mechanized works. Moreover, a detailed structure of } \\
\text { manual and mechanized works was presented. It was stated, inter alia, } \\
\text { that labour consumption of apple production is approximately four } \\
\text { times higher in comparison to black currant and gooseberry. No } \\
\text { impact of the plantation size on the total work inputs on fruit produc- } \\
\text { tion was reported. }\end{array}$} \\
\hline $\begin{array}{l}\text { Key words: } \\
\text { apples, } \\
\text { black current, } \\
\text { gooseberry, } \\
\text { labour consumption of production } \\
\text { mechanization of works }\end{array}$ & \\
\hline
\end{tabular}

\section{Introduction}

Poland belongs to leading countries in Europe and even around the world, with regard to fruit production (Jabłońska and Olewnicki, 2014, Ciebień et al., 2015, Kraciński, 2014, Bieniek-Majka, 2015). The total fruit production from trees in 2016 was estimated as 4064.7 thousand tones i.e. at the level of approx. 14.8\% higher than in 2015 and considerably higher than in the previous years. Fruit harvest obtained from fruit bushes and berry plantations in orchards and strawberry harvest and ground berries harvest were 579.0 thousand tonnes in 2016 (they were $14.1 \%$ higher than the total harvest obtained from orchards in the previous year and decisively higher in comparison to previous years (https://stat.gov.pl/download/gfx/pl/wyniki_produkcji_roslinnej_w_2016.pdf). Orchar production is a specialist one and is characterised by specificity. Its properties are as follows:

- considerably high labour consumption,

- difficulties concerning mechanization of some works,

- a lot of work in some periods of time,

- improperly functioning marketing outlets causing difficulties with the sale of fruit by producers,

- very high fluctuations of the purchase prices in subsequent years,

- considerable production costs.

${ }^{1}$ This Research was financed by the Ministry of Science and Higher Education of the Republic of Poland 
Especially, first four properties cause impediments in organization of works and thus, inter alia, employment of a relevant number of employees, they result in improper proportions between work inputs related to production and sale. The following authors have dealt with the issues of labour consumption of fruit production in their papers: Brzozowski, Zmarlicki (2014), Kowalczyk (2006), Brzozowski and Zmarlicki (2011). A considerably high labour consumption of fruit production is a problem not only in Poland but also in other European countries (Strapatsa et al., 2006). As long as considerable labour consumption of production only few years before was an opportunity to improve the situation of the hidden unemployment on rural areas, as much there are deficiencies in the amount of people to work in rural areas and the situation has changed diametrically. For a person who manages a farm, labour force costs, particularly costs related to harvesting, are becoming particularly significant, since this action cannot be usually replaced effectively with another factor of production (Paszko, 2008). Additionally, a very unstable situation on the fruit purchase market is a problem, where prices offered to producers sometimes do not encourage employment of seasonal workers during harvest, whose salary expectations are getting higher. Higher mechanization of production technology could be a solution to the problem of labour force demand in the period of loading of tasks, which, however, is a serious problem due to considerable costs of specialist machines and high distribution of orchard production. Efficient machines e.g. for harvesting will not find a sufficient work front in small farms, which will result in high costs of their maintenance and will on the other hand affect the production profitability.

\section{Objective and scope of the study}

The objective of the paper was analysis of the level and structure of work inputs in production of selected fruit in relation to the plantation size. The scope of the paper covered three types of fruit, namely; apples, black currant and gooseberry, varied on account of the surface area of a plantation and cultivated in multiple area horticultural farms on the area of Małopolska and Podkarpacie.

\section{Methodology of research}

The research covered 85 horticultural farms located on the area of the following communes: Limanowa, Raciechowice oraz Łańcut. Research consisted in registration of the entire year of farming events which enables determination of applied production technologies which, on the other hand, enabled a detailed analysis of labour inputs. Analysis of labour inputs was made in the plantation groups, separated from farms in relation to the surface area of a plantation.

In case of apples the following were distinguished:

- group I - up to 3.00 ha (16 plantations),

- group II - 3.01-6.00 ha (15 plantations),

- group III - above 6.00 ha (15 plantations). 
Labour consumption of production...

In case of black currant and gooseberry the following were distinguished:

- group I - up to 1.50 ha (12 plantations of black currant and 10 of gooseberry),

- group II 01.51 -3.00 ha (10 plantation of black currant and 10 of gooseberry),

- group III - above 3.00 ha (10 plantations of black currant and 10 of gooseberry).

In particular groups the following were calculated: manual works inputs (man-hour $\cdot \mathrm{ha}^{-1}$ ) inputs of mechanized works (man-hour $\cdot \mathrm{ha}^{-1}$ ), total work inputs (man-hour $\cdot \mathrm{ha}^{-1}$ ), level of work mechanization $(\%)$. Works mechanization level $\left(\mathrm{W}_{\mathrm{m}}\right)$ was calculated as a participation of works performed with the use of technical means of production in the total labour inputs in fruit production (Zaremba 1985):

$$
\mathrm{Wm}=\left(\frac{\mathrm{Lm}}{\mathrm{Lc}}\right) \cdot 100(\%)
$$

where:

$$
\begin{array}{ll}
\mathrm{W}_{\mathrm{m}} & \text { - works mechanization level }(\%), \\
\mathrm{L}_{\mathrm{m}} & - \text { mechanical works inputs }\left(\mathrm{h} \cdot \mathrm{ha}^{-1}\right), \\
\mathrm{L}_{\mathrm{c}} & - \text { total work inputs }\left(\mathrm{h} \cdot \mathrm{ha}^{-1}\right) .
\end{array}
$$

\section{Research results}

The average surface area of farms selected for the study was lower than the average in Poland which is presented in table 1 . In the investigated farms, among horticultural crops, apple orchards prevailed, which occurred in $54 \%$ of farms, and the average area of crops was 5.5 ha. Except for apples, berry fruit were also cultivated, inter alia, black currant they occurred in $38 \%$ of farms and the average area of a plantation was 1.9 ha and gooseberry - occurred in $35 \%$ of farms, and the average surface area was 1.6 ha (table 1). Majority of farms produced one type of fruit, although in some part, production of two types of fruit, mainly currant and gooseberry was carried out. Table 1 presents also the number of employed which included mainly farm owners and living together family members, who considerably help in production works. Except for apples, crops of black currant and gooseberry were not too high. Acc. to Sava (2011) correctly held and watered plantation of gooseberry may cause the increase of crops even up to $32 \mathrm{t} \cdot \mathrm{ha}^{-1}$.

Table 1.

Characteristic of production of selected fruit

\begin{tabular}{lcccc}
\hline Specification & $\begin{array}{c}\text { Surface area of } \\
\text { cultivation } \\
\text { Min.-max. (average) } \\
(\text { ha) }\end{array}$ & $\begin{array}{c}\text { Crop } \\
\text { Min.-max. } \\
\text { (average) } \\
\left(\mathrm{t} \cdot \mathrm{ha}^{-1}\right)\end{array}$ & $\begin{array}{c}\text { Total farm area } \\
\text { Min.-max. } \\
\text { (average) } \\
\text { (ha) }\end{array}$ & $\begin{array}{c}\text { Employed } \\
\text { in a farm } \\
\text { Min.-max. } \\
\text { (average) } \\
\text { (persons) }\end{array}$ \\
\hline Apples & $1.2-17.8(5.5)$ & $29.0-54.5(41.5)$ & $3.4-19.2(8.1)$ & $2-7(4.1)$ \\
Black currant & $0.9-5.2(1.9)$ & $3.8-10.8(5.2)$ & $2.1-12.4(7.3)$ & $1-6(3.2)$ \\
Gooseberry & $0.8-3.6(1.6)$ & $4.1-11.5(6.1)$ & $2.1-14.1(7.6)$ & $2-6(3.3)$ \\
\hline
\end{tabular}


Table 2 sets the following: work mechanization level and labour inputs divided into manual and mechanical works. Manual works, regardless the fruit type prevail in the total labour inputs, which can be proved by the works mechanization level, which is within $18 \%$ - in case of apples, to $47 \%$ in case of gooseberry. Generally, the most mechanized production occurs in the biggest plantations and concerns all three types of fruit. To compare, grain mechanization level exceeds in general $80 \%$ (Kowalczyk, 2011). Fruit production is highly labour consuming. The total labour inputs are the highest in apple production and are within 643-807 man-hour-ha ${ }^{-1}$. Research by Strapatsa et al., (2006) shows that labour inputs related to apple production in Greece are at a slightly lower level, namely 530 manhour $\mathrm{ha}^{-1}$. In case of gooseberry and currant these inputs are considerably lower and are respectively: 198-232 man-hour-ha ${ }^{-1}$ and 177-204 man-hour-ha ${ }^{-1}$. The research by Kowalczyk (2006) shows that black currant and gooseberry production is labour consuming at the level of respectively: 193 man-hour $\cdot \mathrm{ha}^{-1}$ and 158 man-hour $\cdot \mathrm{ha}^{-1}$.

Analysis of the total work inputs in area groups shows that it is difficult to find significant relations of labour consumption to the surface area. In case of apples and currant - the highest total labour inputs occur in the central area groups, and gooseberry production is completely different. The highest labour consumption of currant and gooseberry production occurs in groups, where at the same time the average age of a plantation is the highest. Reported higher crops and higher labour inputs related to formation of bushes on older plantations may cause a considerably higher labour consumption.

Table 2.

Age of plantation and labour inputs in production of selected fruit

\begin{tabular}{|c|c|c|c|c|c|}
\hline Specification & $\begin{array}{c}\text { Average age of } \\
\text { a plantation } \\
\text { (years) }\end{array}$ & $\begin{array}{c}\text { Mechanical } \\
\text { works } \\
\left({\left.\text { man-hour } \cdot h a^{-1}\right)}\right.\end{array}$ & $\begin{array}{c}\text { Manual } \\
\text { works } \\
\left(\text { man-hour } \cdot h a^{-1}\right) \\
\end{array}$ & $\begin{array}{c}\text { Total } \\
\left(\text { man-hour } \cdot h a^{-1}\right)\end{array}$ & $\begin{array}{c}\text { Works } \\
\text { mechanization } \\
\text { level }(\%) \\
\end{array}$ \\
\hline \multicolumn{6}{|l|}{ Apples } \\
\hline up to 3.00 ha & 14 & 132 & 511 & 643 & 21 \\
\hline $3.01-6.00 \mathrm{ha}$ & 11 & 147 & 660 & 807 & 18 \\
\hline above 6.00 ha & 9 & 163 & 527 & 690 & 24 \\
\hline \multicolumn{6}{|l|}{ Black currant } \\
\hline up to $1.50 \mathrm{ha}$ & 6 & 71 & 127 & 198 & 36 \\
\hline $1.51-3.00 \mathrm{ha}$ & 7 & 91 & 141 & 232 & 39 \\
\hline above 3.00 ha & 5 & 88 & 121 & 209 & 42 \\
\hline \multicolumn{6}{|l|}{ Gooseberry } \\
\hline up to 1.50 ha & 8 & 85 & 119 & 204 & 42 \\
\hline $1.51-3.00 \mathrm{ha}$ & 6 & 80 & 97 & 177 & 45 \\
\hline above 3.00 ha & 6 & 92 & 102 & 194 & 47 \\
\hline
\end{tabular}

The research helped us to carry out statistical analysis in the form of analysis correlation. The area of a plantation was assumed as an independent variable, on the other hand, inputs of mechanical, manual works and the total labour consumption for all three fruit types were assumed as dependent variables. Results were presented in table 3. Clear rela- 
Labour consumption of production...

tion was reported only between the plantation area and the size of mechanical works in apple production.

Table 3.

Values of correlation coefficients between the plantation area and labour inputs in fruit production

\begin{tabular}{lccc}
\hline Fruit & $\begin{array}{c}\text { Mechanical } \\
\text { works }\end{array}$ & $\begin{array}{c}\text { Manual } \\
\text { works }\end{array}$ & $\begin{array}{c}\text { Total } \\
\text { labour consumption }\end{array}$ \\
\hline Apples & 0.34 & 0.08 & 0.15 \\
Black currant & 0.16 & -0.18 & -0.03 \\
Gooseberry & 0.14 & -0.17 & -0.05 \\
\hline
\end{tabular}

A detailed structure of work inputs in fruit production was presented in table 4. In case of apples the most labour consuming are: post-harvest treatment as well as sale and harvesting. The highest labour consumption of post-harvest treatment and sale (183 man-hour-ha $\left.{ }^{-1}\right)$ results mainly from badly organized apple outlet market. The producers which were covered by the research cooperated with wholesalers or big supermarkets only to a small extent and generally they were selling the produced apples. The sale took place in agri-food fairs and markets and consumed great time inputs. Rarely, producers came from a fair without selling even a half of the offered goods. High labour consumption of apple harvest (176 man-hour ha ${ }^{-1}$ ) results mainly from the total manual harvest. The structure of work inputs in case of berry fruits, where works related to cutting branches (57 and 67 man-hour-ha ${ }^{-1}$ ) prevailed. These are actions, also quite difficult for full mechanization and made manually with the use of cutting shears. Harvest of currant and gooseberry was mainly carried out with combines. On the other hand, distribution of currant and gooseberry was better organized than in case of apples. These fruit were sold in big amounts to processing plants, thus lower inputs of work related to their sale. Other works included mainly transport of fruit.

Table 4.

Detailed labour consumption of production of selected fruit

\begin{tabular}{lccc}
\hline & \multicolumn{3}{c}{$\begin{array}{c}\text { Labour inputs } \\
\left.\text { Sman-hour·ha }{ }^{-1}\right)\end{array}$} \\
\cline { 2 - 4 } & Apples & $\begin{array}{c}\text { Black } \\
\text { currant }\end{array}$ & Gooseberry \\
\hline Soil maintenance & 34 & 27 & 20 \\
Fertilization & 20 & 16 & 11 \\
Chemical protection & 41 & 30 & 26 \\
Winter cutting & 81 & - & - \\
Summer cutting & 54 & - & - \\
Pruning & - & 57 & 67 \\
Chemical thinning & 74 & - & - \\
Harvest & 176 & 21 & 27 \\
Post-harvest treatment and distribution & 183 & 38 & 14 \\
Other works & 34 & 20 & 181 \\
Total & 697 & 209 & \\
\hline
\end{tabular}


Table 5 presents the structure of work inputs divided into manual and mechanized works. Taking into consideration technical equipment of farms covered with the research, one may state that they in majority owned specialist tractor sprayers, tractor mowers, fertilizer spreaders adjusted to work in orchards and transport means. In case of farms dealing with cultivation of gooseberry and black currant, over a half was equipped with combine harvesters for gooseberry and black currant, while the others used the neighbours' help as a part of performed services or renting a combine.

Table 5.

Structure of inputs of mechanical and manual work

\begin{tabular}{|c|c|c|c|}
\hline \multirow{2}{*}{ Specification } & \multicolumn{3}{|c|}{$\begin{array}{l}\text { Inputs of the mechanized work } \\
\qquad(\%)\end{array}$} \\
\hline & Apples & $\begin{array}{c}\text { Black } \\
\text { currant }\end{array}$ & Gooseberry \\
\hline Soil maintenance & 26 & 24 & 23 \\
\hline Fertilization & 16 & 14 & 13 \\
\hline Chemical protection & 32 & 26 & 31 \\
\hline Harvest & - & 18 & 17 \\
\hline Other works & 26 & 18 & 16 \\
\hline \multirow[t]{2}{*}{ Total } & 100 & 100 & 100 \\
\hline & \multicolumn{3}{|c|}{ Inputs of manual work (\%) } \\
\hline Winter cutting & 14 & - & - \\
\hline Summer cutting & 10 & - & - \\
\hline Pruning & - & 60 & 71 \\
\hline Chemical thinning & 13 & - & - \\
\hline Harvest & 31 & - & - \\
\hline Post-harvest treatment and distribution & 32 & 40 & 29 \\
\hline Total & 100 & 100 & 100 \\
\hline
\end{tabular}

Chemical plant protection treatments have the biggest participation in mechanical works. Especially in apple orchards, many, even several treatments of chemical spraying were carried out. The number of applied chemical plant protection treatments was higher in case of the biggest plantations and differences were even up to 3-4 treatments with regard to smaller plantations. For the biggest plantations, also, more intense fertilization was applied, but the difference in the number of treatments made was not as considerable as in case of plant protection. Such a state of affairs may be justified with a bigger care for the condition of plants on big, commodity plantations. On the second position, with regard to mechanical works, there is maintenance of soil between rows. These works aimed at grass mowing (with the use of tractor mowers) - mainly in some apple orchards or maintenance of the socalled 'black fallow" (with the use of herbicide spraying with tractor sprayers) in case of all fruit types. In the structure of manual works, in apple production, works related to harvesting, post-harvest treatment and distribution prevail, which in total over $60 \%$ of all manual works. In case of black currant and gooseberry, branch pruning is decisively the most time consuming manual work which consumes respectively $60 \%$ and $71 \%$ of all inputs of manual work. As long as branch pruning itself took place manually, with the use of pruning shears, as much removal of branches was sometimes mechanized, namely, in case of bigger 
Labour consumption of production...

plants, branches were ground before disposal, which not always took place in smaller orchards. Post-harvest treatment of berry fruits consisted mainly in their preparation for sale, namely, manual cleaning of fruit by removal of leaves and other contaminations. Generally speaking, in farms covered by the research, more similar production technologies were used, based on the use of the same types of technical production means. Differences concerning the size of labour inputs of majority of actions and treatments resulted from organizational problems, namely, the number of persons that carry out manual works. The number of the employed people on the same plantation was varied on particular days, and even day times. On account that the total time of the shift $-\mathrm{T}_{07}$ constituted the basis for calculation of labour consumption (Banasiak, 2008) distance between orchards and farms, changing weather conditions, organizational brakes and other had a significant impact on labour inputs.

\section{Summary and conclusions}

Based on the research which was carried out, it was found out that:

1. The highest level of work mechanization in production of all fruit takes place in plantations with the biggest area and in case of black currant and gooseberry, the mechanization degree grows with the increase of the plantation area. The above relations result, inter alia, from a higher number of chemical protection treatments and fertilization applied in big plantations and simultaneously better organization of work during branch pruning.

2. Unit total work inputs (man-hour-ha ${ }^{-1}$ ) in fruit production do not depend on the plantation size which is proved by correlation analysis. Cause of differences concerning labour inputs in particular plantations do not result from technology (which are very similar) but it should be assumed that they result from organizational aspects of works.

3. Difficulties with mechanization of works related to harvesting and post-harvest treatment and distribution of apples cause that the total labour consumption is over threefold higher than in case of currant and gooseberry. Unfortunately quality requirements concerning apples for direct consumption, not processing and the production scale rather exclude opportunities of application of harvesting machines for a bigger scale.

4. Over one fourth of the total labour consumption of apple production is taken by their distribution, which results from improperly functioning outlet market. Improvement of outlet markets organization may ensure, except for limitation of labour consumption, also reduction of production costs and a feeling of bigger stabilization and limitation of the risk of apple producers.

\section{References}

Argiro, V., Strapatsa, G., Nanos,_D., Constantinos, A. (2006). Energy flow for integrated apple production in Greece. Agriculture, Ecosystems \& Environment. Volume 116, Issues 3-4, 176-180.

Banasiak, J. (2008). Wydajnościowa analiza w procesach eksploatacji maszyn rolniczych Inżynieria Rolnicza, 4(102), 63-68.

Bieniek-Majka, M. (2015). Determinanty eksportu owoców i warzyw z Polski w latach 2004-2014. Stowarzyszenie ekonomistów rolnictwa i agrobiznesu, Roczniki Naukowe, XVII, 4, 32-38. 
Brzozowski, P., Zmarlicki, K. (2011). Nakłady pracy własnej i najemnej w gospodarstwach z uprawą truskawek dla przetwórstwa a wielkość i opłacalność produkcji. Zeszyty Naukowe Instytutu Sadownictwa i Kwiaciarstwa im. Szczepana Pieniązka, 19, 43-49.

Brzozowski, P., Zmarlicki, K. (2011). Nakłady pracy własnej i najemnej w gospodarstwach z uprawą jabłoni i wiśni a wielkość i opłacalność produkcji. Zeszyty Naukowe Instytutu Sadownictwa i Kwiaciarstwa im. Szczepana Pieniażka, 19, 33-41.

Brzozowski, P., Zmarlicki, K. (2014). Pracochłonność i koszty pracy w produkcji jabłek w gospodarstwach z produkcją ekologiczną i konwencjonalną. Roczniki naukowe ekonomii rolnictwa i rozwoju obszarów wiejskich, 3(101), 36-42.

Ciebień, M., Rachoń, L., Krawiec, P. (2015). Pozycja Polski w światowej produkcji malin w latach 2003-2012. Stowarzyszenie ekonomistów rolnictwa i agrobiznesu, Roczniki Naukowe. XVII, 2, 16-19.

Jabłońska, L., Olewnicki, D. (2014). Rozwój i znaczenie sektora ogrodniczego w Polsce w ostatnim półwieczu. Roczniki naukowe ekonomii rolnictwa i rozwoju obszarów wiejskich, 3(101), 25-35.

Kowalczyk, Z. (2006). Poziom i struktura nakładów pracy w wybranych gospodarstwach sadowniczych. Inżynieria Rolnicza, 11, 209-214.

Kowalczyk, Z. (2011). Poziom i struktura zużycia technicznych środków trwałych w różnych typach gospodarstw rolniczych. Rozprawa habilitacyjna. Inżynieria Rolnicza, 2(127), 1-117.

Kraciński, P. (2014). Zbiory i rozdysponowanie produkcji truskawek, malin i porzeczek w Polsce w latach 2001-2012. Roczniki naukowe ekonomii rolnictwa i rozwoju obszarów wiejskich, 2(101), 132-140.

Paszko, D. (2008). Wpływ zmienności kosztów siły roboczej na opłacalność produkcji owoców jagodowych. Zeszyty Naukowe Instytutu Sadownictwa i Kwiaciarstwa im. Szczepana Pieniąża, 16, 223-234.

Sava, P. (2011). Study on fruits production of densely gooseberry bush plantation. Lucrări Stiintififice Universitatea de Ştiințe Agronomice și Medicină Veterinară București. Seria B, Horticultură, No. $55,432-435$.

Zaremba, W. (1985). Ekonomika i organizacja mechanizacji rolnictwa. PWRiL. Warszawa https://stat.gov.pl/download/gfx/.../pl/.../wyniki_produkcji_roslinnej_w_2016.pdf

\section{PRACOCHLONNOŚĆ PRODUKCJI WYBRANYCH OWOCÓW}

Streszczenie. Celem pracy była analiza poziomu nakładów robocizny w produkcji trzech wybranych owoców (jabłek, porzeczki czarnej oraz agrestu), w tym między innymi w zależności od powierzchni plantacji. Obliczono całkowite nakłady robocizny, z podziałem na prace wykonywane ręcznie oraz zmechanizowane. Przedstawiono także szczegółową strukturę nakładów prac ręcznych oraz zmechanizowanych. Stwierdzono $\mathrm{m}$. in. ok. cztery razy większą pracochłonność produkcji jabłek w porównaniu do porzeczki i agrestu, a także zdecydowaną przewagę nakładów prac ręcznych nad zmechanizowanymi. Nie odnotowano wpływu wielkości plantacji na całkowite nakłady pracy na produkcję owoców.

Słowa kluczowe: jabłka, porzeczka czarna, agrest, pracochłonność produkcji, mechanizacja prac 